Original research article

\title{
The impact of nurse manager caring behaviors and work environment on burnout syndrome among nurses
}

\author{
Kuswantoro Rusca Putra ${ }^{1 *}$, Heriandi Sutadi ${ }^{2}$, Setyowati Setyowati ${ }^{3}$, Rr. Tutik Sri Hariyati ${ }^{3}$ \\ ${ }^{1}$ University of Brawijaya, Faculty of Medicine, School of Nursing, Malang, Indonesia \\ ${ }^{2}$ University of Indonesia, Faculty of Dentistry, Depok, Indonesia \\ ${ }^{3}$ University of Indonesia, Faculty of Nursing, Depok, Indonesia
}

\begin{abstract}
Nursing is a profession that entails a high risk of burnout, so effective organizational management is needed to reduce its occurrence. This study aims to investigate the moderating effects of Nurse Manager caring behaviors and work environment in burnout syndrome among nurses. This study design uses exploratory descriptions with a cross-sectional approach and considers a sample of 485 nurses in the medical surgical wards at three general hospitals in East Java Province, Indonesia. Data collection was performed using three separate questionnaires: The Maslach Burnout Inventory-Human Service Survey (MBI-HSS) to identify burnout syndrome among nurses, Caring Assessment Tool: Administration (CAT: Admn) to identify caring behaviors in nurse managers, and My Relationship with Work test (MRW) to identify work environments. The data was analyzed using Partial Least Square analysis. Nurse manager caring behaviors have a direct effect on personal accomplishment among nurses. The caring behaviors of nurse managers influence control, workload, community, fairness, reward and value. Caring behaviors from nurse managers also affect emotional exhaustion and depersonalization through the mediation of rewards, controls and workload.
\end{abstract}

Keywords: Burnout; Caring; Leader; Nurse; Work environment; Worklife

\section{Introduction}

Burnout is a psychological syndrome that involves a prolonged response to interpersonal stressors that are chronic in a person's work. Burnout usually occurs in health professions which are characterized by emotional exhaustion, depersonalization, and personal accomplishment (Yuan and $\mathrm{Xu}, 2020$ ). Healthcare professionals often experience burnout (Chemali et al., 2019; Dubale et al., 2019). The results of the study revealed that nurses around the world have high burnout prevalence rates (Hailay et al., 2020; Shah et al., 2021; Woo et al., 2020). Worldwide studies on nurse burnout syndrome are often found in emergency or critical care settings have proved that burnout is a common problem in many countries (Adriaenssens et al., 2015; Alharbi et al., 2016; Hamed et al., 2020; Nobre et al., 2019). Moreover, a study showed that there was a lower incidence of burnout in medical surgical nurses compared to critical care (Mahmoudi et al., 2020) and emergency nurses (Harkin and Melby, 2014). Medical surgical wards are a large area within the hospital. A large number of nurses take care of many patients in medical surgical wards. If these nurses experience burnout syndrome, the quality of care service to patients will have an impact (Ramirez-Baena et al., 2019). This condition, if not managed properly, will have an impact on the condition of the nurse and his or her performance in providing clinical services at the hospital (Dall'Ora et al., 2020).

Factors that contribute to burnout can be divided into two groups: (1) individual and socio-demographic factors; and (2) organizational and environmental factors (McCormack and Cotter, 2013). Some studies related to individual and socio-demographic factors have found results that associate these factors with the occurrence of burnout, but other studies have found the opposite to be the case (McCormack and Cotter, 2013). One approach to prevent burnout is through healthy work environment (Kim et al., 2020). The incidence of burnout nurses is higher where the work environment is poorly managed. Burnout is correlated with violence, distress, and lack of support at the workplace (Aronsson et al., 2017; Chemali et al., 2019; Havaei et al., 2020). Poor working environment will have an impact on the incidence of burnout. As many as $42.9 \%$ of nurses experience high emotional fatigue; $32.1 \%$ experience high depersonalization and 52.5\% experience a high decline in self-performance (Zhang et al., 2014). Moreover, several studies have mentioned how a poor work environment impacts nurse turnover, job dissatisfaction and

\footnotetext{
* Corresponding author: Kuswantoro Rusca Putra, University of Brawijaya, Faculty of Medicine, School of Nursing, Malang, Indonesia; e-mail: torro.fk@ub.ac.id http://doi.org/10.32725/kont.2021.019

Submitted: 2020-10-31 • Accepted: 2021-04-12 • Prepublished online: 2021-04-19 
the desire to change employer (Aiken et al., 2012; Coetzee et al., 2013). These findings indicate the need for good management of the work environment in order to reduce the incidence of burnout and its negative impact on nurses and patient care.

There are six aspects of the work environment that affected the occurrence of burnout: workload, control, reward, fairness, community and value at work (Maslach and Leiter, 2008). The successful management of a nurse's working environment in order to reduce the incidence of burnout requires the role of a leader. Leadership in the hospital ward has an important role in creating a good work environment (Roche et al., 2015). The supportive role of the ward manager is attributed to facilitating superior nursing practice, improving nurses' confidence, enhancing teamwork and providing better work environments (Oshodi et al., 2019).

Nursing managers' leadership style had a significant negative correlation with emotional exhaustion, depersonalization, and reduced personal accomplishment (Ebrahimzade et al., 2015). The important role of the nurse manager in realizing a good work environment can entail creating, managing and if necessary, rebuilding a caring work culture. A caring approach is often used in interactions with patients but is rarely discussed and used in the workplace because it is perceived as a sensitive topic. The essence of caring in nursing and the need to care for caregivers are emphasized. Nurses who apply caring in contemporary clinical practice must begin with caring for caregivers (Tang et al., 2019). Caring is a main foundation of nursing practice. Nurses must take care of themselves before caring for others, and currently this not a priority. A caring approach can make the work process more efficient. Sufficient workload and determining work-life balance boundaries can be the key to a good environment (Waddill-Goad, 2019). Furthermore, caring behaviors of nurse managers and colleagues is also important in creating a good work environment for nurses (Longo, 2011).

A healthy work environment should begin with positive interpersonal relationships and respect between nurse managers and nursing staff. Positive collaboration between nurse managers and staff will be conducive to creating a caring work environment. Nurses who feel appreciated by their managers are in turn encouraged to build positive and caring interactions with their patients (Cara et al., 2011). In other words, caring managers positively influence the caring behaviors of nursing staff.

Burnout in the nursing profession is high due to the scale of professional demands (Cheng et al., 2015). Managers need to recognize this as early as possible. Nurse managers should take action to reduce job burnout in the working environment through caring behaviors. Caring behavior should be addressed properly by managers as it is associated with emotional tiredness, depersonalization, and achievement (Shen et al., 2018). Managers who are alert to the nurses' working situations will have a positive impact and reduce burnout (Holland et al., 2013). In order for it to be diminished, the high prevalence of burnout in nursing needs the positive influence of nurse managers with a caring behavior approach.

Based on the above justification, this research was conducted to explore the impact of caring behaviors by nurse managers and work environment on the incidence of burnout syndrome in nurses. The purpose of this study was to determine the direct effect of nurse manager caring behavior and the work environment of nurses on the burnout of nurses in the hospital, and the indirect effect of caring behavior of nurse managers that is mediated by the work environment on symptoms of nurse burnout.

\section{Materials and methods}

The research design was based on an explorative correlational survey with a cross-sectional approach.

The study population comprised nurses who worked in the Medical Surgical Ward at government general hospitals in East Java Province of Indonesia. The sample was gathered using consecutive sampling. The study population was divided into three groups based on hospitals located in three different areas: (1) capital of the province, (2) municipality, and (3) district. One hospital was allocated to each group. The purpose of the stratification was to obtain a greater degree of sample representativeness and to be able to include respondents from various government general hospital locations.

The total number of nurses on duty in medical surgical areas during the data collection in government hospitals in group 1 was as many as 250 nurses, group 2 as many as 250 nurses, and group 3 as many as 125 nurses.

\section{Data collection procedure}

To determine the appropriate number of participants, the intended sample size was calculated using a formula for sample size estimation in a cross-sectional study. Based on a significance level alpha value of 0.05 and an estimated $p$ value of 0.50 , a minimum sample size of 385 nurses was determined. Data collection was carried out between April 12, 2018 and May 25, 2018. The researcher visited the Medical Surgical Ward at three hospitals to explain the purpose of the study, obtain the nurses who would become the respondents in the study and to distribute the questionnaire. Paper-based questionnaires were sent to the head of the ward be given to nurses who had worked for at least 1 year, were not sick, and did not take leave during the data collection period. After three days, the questionnaire was returned to the head of the ward in a sealed envelope.

The questionnaires were sent to 625 nurses, of which 250 were chosen from group 1, (returned 200) 250 from group 2, (returned 230) and 125 from group 3, (returned 110). Fifty-five questionnaires were excluded from the final analysis due to missing values or the fact that the respondents did not work in medical or surgical wards during the preceding year. After the exclusion of these questionnaires, the sample consisted of 485 respondents.

This research received ethical approval from the Ethical Committee in Health Research Dr. Saiful Anwar and Dr. Soetomo general hospital (Approval No. 400/20/K.3/302/2017; No. 0314/KEPK/V/2018). All respondents who participated in this study had previously provided informed consent. Participants fully understood the research and agreed to respond to the questionnaires. The entire survey process implemented anonymity and all personal information was kept confidential as required by the Personal Data Protection in Electronic Systems (PDP Regulation).

\section{Instruments}

Data collection was performed using three tools: the MBI-HSS questionnaire, the CAT-admin questionnaire (Wolverton et al., 2018) and the MRW questionnaire (Leiter and Maslach, 2005). Respondents answered questions on the MBI-HSS questionnaire by quantifying their experience in a rating scale ranging from 0 = "Never" to 6 = "Every day". There were 22 questions with details to measure emotional exhaustion (nine items), depersonalization (five items) and personal accomplishment (eight items). The lower the emotional exhaustion and dep- 
ersonalization scores, the better the interpretation is, and the higher the personal accomplishment score, the better the interpretation. Permission was obtained from Mind Garden (Mind Garden Inc., Menlo Park, CA) to use an Indonesian version of MBI-HSS. The CAT-Admn questionnaire compromised 25 items with a rating scale ranging from 1 = "Never" to $5=$ "Always". The higher the scores, the better the interpretation. The MRW questionnaire consisted of 60 items with details regarding control (10 items), workload (10 items), community (10 items), rewards (10 items), fairness (10 items), and value (10 items) with ratings of $0=$ "Just Right", 1 = "Mismatch" and 2 = "Major Mismatch". The interpretation is good if the scores are lower. The CAT-Admn and MRW questionnaires were translated into the Indonesian language and then back-translated blindly into English by two qualified translators. As a cross check, the original Indonesian translator checked the equivalence of the two English versions of the instruments. The questions in the Indonesian versions were formulated with the same content as the items in the original, taking into account the cultural characteristics of the Indonesian health care system.

\section{Data analysis}

The data was analyzed using Smart PLS 3. This statistical test included outer test model to evaluate validity and reliability indicator. A valid indicator was considered to have a loading factor 20.60 . A reliable indicator showed a composite reliability $>0.60$. The nurse manager caring behavior variables of the 25 factors were all valid. Among the control variables of 10 factors there are 7 valid and 3 invalid factors. From workload variables of 10 factors there are 4 valid and 6 invalid factors. The community had 9 valid factors with 1 invalid, the reward had 8 valid factors with only 2 invalid. The value item showed 10 factors as valid and the number for fairness was 8 valid factors. From the 9 emotional exhaustion factors there are 8 valid factors and 1 invalid. Depersonalization had 5 valid factors with 1 invalid, and personal accomplishment showed all 8 factors as valid. Variables are said to be reliable if the composite reliability value and Cronbach alpha $>0.70$. Composite reliability values of each variable were as follows: nurse manager's caring behavior (0.97), control (0.88), workload (0.82), community (0.92), reward (0.87), fairness (0.90), value (0.91), emotional exhaustion (0.88), depersonalization (0.80), and personal accomplishment (0.89). An inner test model or hypothesis test was done after all the data was valid and reliable $(p<0.50)$.

\section{Results}

Table 1 shows the sociodemographic characteristics of the respondents. Respondents of this study were mostly women, aged between 20-30 years, educated to Nursing Diploma, employment status as non-government employee, the modal marital status was married, and work experience ranged from 1 to 5 years.

Based on Table 2, using a confidence level of 95\%, the score of the nursing work environment is perceived by nurses as being a nurse manager's caring behavior score between 83.05-86.74; workload score is between 3.16-3.71; control score between 1.89-2.40; community scores between 2.13-2.72; rewards score between 3.31-3.94; fairness score between 3.00-3.64 and value score is between 2.15-2.76. Burnout symptoms as perceived by nurses were emotional ex-

\section{Table 1. Sociodemographic characteristics of respondents} $(n=485)$

\begin{tabular}{|c|c|c|}
\hline & $n$ & $\%$ \\
\hline \multicolumn{3}{|l|}{ Sex } \\
\hline Male & 188 & 38.8 \\
\hline Female & 297 & 61.2 \\
\hline \multicolumn{3}{|l|}{ Age group (years) } \\
\hline $20-30$ & 229 & 47.2 \\
\hline $31-40$ & 142 & 29.3 \\
\hline $41-50$ & 80 & 16.5 \\
\hline$>50$ & 34 & 7 \\
\hline \multicolumn{3}{|l|}{ Education } \\
\hline Nursing diploma & 317 & 65.4 \\
\hline Bachelor & 168 & 34.6 \\
\hline \multicolumn{3}{|l|}{ Employment status } \\
\hline Government employees & 217 & 44.7 \\
\hline Non-government employees & 268 & 55.3 \\
\hline \multicolumn{3}{|l|}{ Marital status } \\
\hline Unmarried & 85 & 17.5 \\
\hline Married & 400 & 82.5 \\
\hline \multicolumn{3}{|l|}{ Duration of nursing work (years) } \\
\hline $1-5$ & 207 & 42.7 \\
\hline $6-10$ & 115 & 23.7 \\
\hline $11-15$ & 42 & 8.6 \\
\hline $16-20$ & 32 & 6.6 \\
\hline$>20$ & 89 & 18.3 \\
\hline
\end{tabular}

Table 2. Statistical distribution of nurse manager's caring behavior, workload, control, community, rewards, fairness, value and burnout syndrome in nurses $(n=485)$

\begin{tabular}{|c|c|c|c|}
\hline Variable & Mean \pm SD & Min-Max & $\mathrm{CI}(95 \%)$ \\
\hline Caring behavior nurse manager & $84.89 \pm 20.68$ & $26-125$ & $83.05-86.74$ \\
\hline Workload & $3.43 \pm 3.49$ & $0-14$ & $3.16-3.71$ \\
\hline Control & $2.15 \pm 2.88$ & $0-13$ & $1.89-2.40$ \\
\hline Community & $2.42 \pm 3.32$ & $0-20$ & $2.13-2.72$ \\
\hline Rewards & $3.63 \pm 3.56$ & $0-20$ & $3.31-3.94$ \\
\hline Fairness & $3.32 \pm 3.59$ & $0-16$ & $3.00-3.64$ \\
\hline Value & $2.46 \pm 3.45$ & $0-20$ & $2.15-2.76$ \\
\hline Emotional exhaustion & $14.02 \pm 9.75$ & $0-51$ & $13.15-14.89$ \\
\hline Depersonalization & $5.67 \pm 5.39$ & $0-25$ & $5.19-6.15$ \\
\hline Personal accomplishment & $37.87 \pm 9.02$ & $6-48$ & $37.07-38.68$ \\
\hline
\end{tabular}


haustion (which scored between 13.15-14.89); depersonalization scored between 5.19-6.15, and personal accomplishment scored between 37.07-38.69.

The analysis showed there is a significant correlation between nurse managers' caring behaviour and rewards (coefficient $=-0.25 ; p=<0.001$ ), fairness (coefficient $=-0.23$; $p=<0.001$ ), control (coefficient $=-0.30 ; p=<0.001$ ), community (coefficient $=-0.20 ; p=<0.001)$, workload (coefficient $=$ $-0.13 ; p=<0.005$ ) and value (coefficient $=-0.22 ; p=<0.001$ ). The value of negative coefficient shows the better the caring behavior of nurse managers, the better the work environment (reward, fairness, control, community, workload and value). There is also a significant association between nurse managers' caring behaviour and personal accomplishment (coefficient = $0.25 ; p=<0.001$ ). The positive coefficient value indicates that the better the nurse manager's caring behavior, the better the nurse's achievement. There is a significant correlation between workload (coefficient $=0.15 ; p=0.013$ ), control (coefficient $=0.19 ; p=0.001$ ) with emotional exhaustion. Thus a significant correlation is found between workload (coefficient $=0.15$; $p=0.013$ ), control (coefficient $=0.16 ; p=0.019$ ) with depersonalization. There was also an important interdependence between reward and emotional fatigue (coefficient $=0.15$; $p=0.044$ ). Finally, there is a significant connection between reward and depersonalization (coefficient $=0.20 ; p=0.007$ ), positive coefficient values indicate that the better the workload, reward and control, the better the emotional exhaustion and depersonalization. Analysis of the results of path coefficients can be seen in Fig. 1.

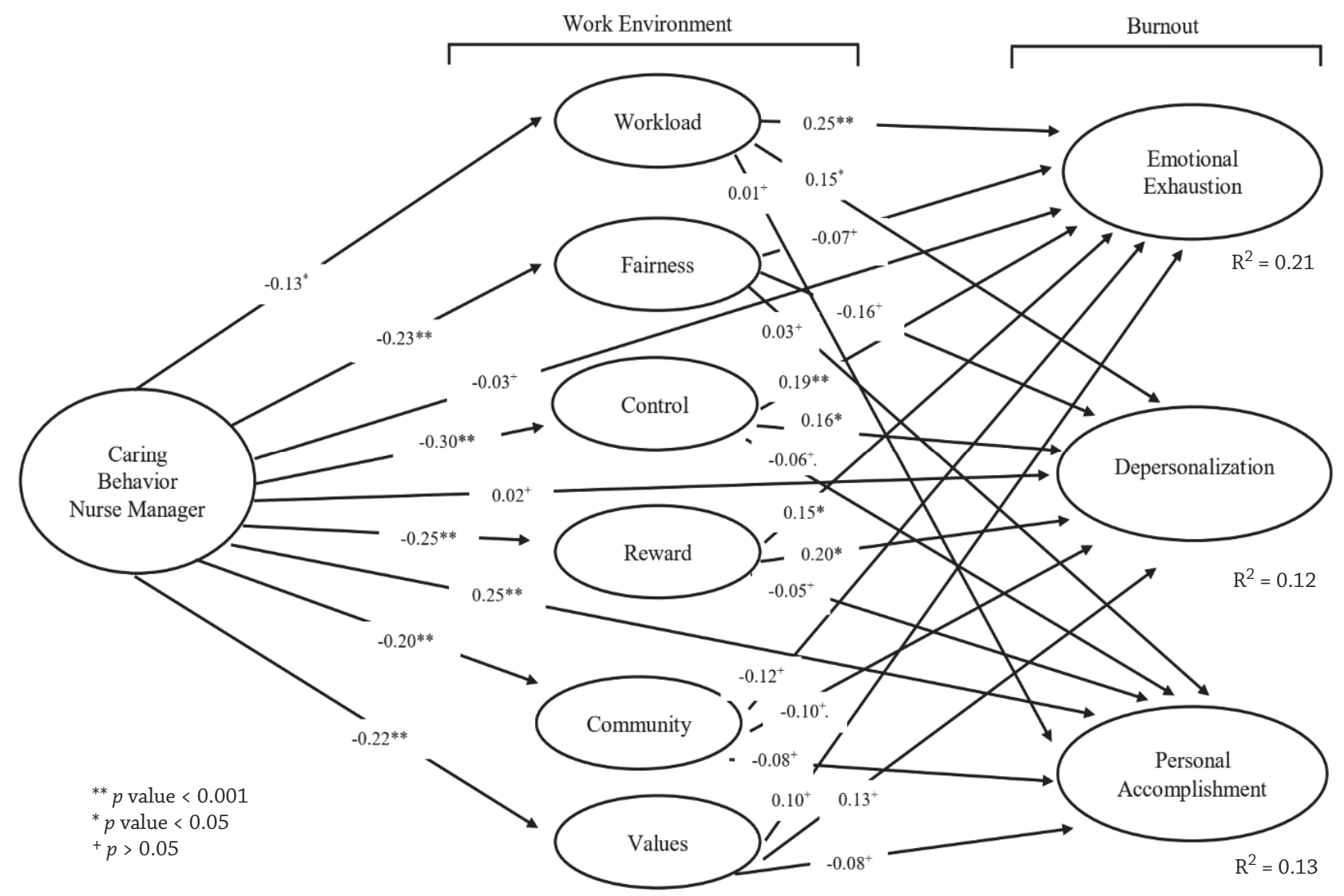

Fig. 1. The results of the analysis path coefficient of the caring behavior of the nurse manager and the work environment in nurse burnout

\section{Discussion}

Caring behavior involves solving common problems, giving full attention, respecting nurses as human, giving hope in an encouraging way, appreciating uniqueness, providing a healing environment and facilitating basic human needs and affiliation (Duffy, 2018). The results of this study indicate that caring behavior that is well implemented by the nurse manager will affect the good work environment - including workload, control, community, reward and value. The nurse manager in the care unit is a leader for nurses. The results of this study are consistent with previous research that good leadership will positively influence workload, control, community, reward, fairness and value in the workplace (Laschinger et al., 2015). Leadership is the foundation of the work environment model and influences other work environment factors. Leaders are the main factor in establishing a good work environment to reduce burnout (Mudallal et al., 2017). The results of this study are also consistent with other studies which found that leaders tend to develop a caring relationship with each follower - and this shows a significant negative effect on burnout (Lee and Ji, 2018; Tafvelin et al., 2019). The results of this study illustrate that caring behavior directly affects personal accomplishment; 
the better the nurse manager's behavior, the better the nurse's performance. This result is in accordance with several other studies which state that there is a positive relation between leadership behavior and nurse achievement (Madathil et al., 2014; Mo and Shi, 2017).

The results of this study found that the better the nurses' perceptions of workload, control and reward by the head of the inpatient unit through caring behavior, the lower the emotional exhaustion and depersonalization of nurses. Workload is the amount of work done or that should be done. The workload in nursing is associated with overwork, inadequate physical structure, excessive working hours, and limited numbers of nurses (de Carvalho et al., 2019). Excessive workloads have a negative impact on individuals and organizations as well as the quality of work results. It also reduces the time available to engage in interaction with colleagues or to build a community, and will cause nurses to experience moral and motivational disturbances (McCormack and Cotter, 2013). In this study, there was a significant correlation between workload and emotional fatigue. This result mirrored several studies which stated that increasing workload has a strong influence on the occurrence of emotional fatigue (Liu and Lo, 2018; Molero et al., 2018; Nguyen et al., 2018; Nishimura et al., 2014). Thus, there was a significant relation between workload and depersonalization. This result agreed with several studies which state that the increasing workload will increase the sense of depersonalization among nurses (Laschinger et al., 2015; Nguyen et al., 2018; Phillips, 2020).

Workload can be divided into two types. Firstly, workload arises from the demands of a highly skilled job in conjunction with too little time available to carry out the demands of the job. Secondly, workload is the product of working in complex roles, which require a high level of concentration. Both types can cause burnout, especially if the employee does not have the opportunity to rest and recover from the demands of the job. Individuals who have the opportunity to rest at work or at home are far more able to recover from the stress of the demands of this work (McCormack and Cotter, 2013). The appropriate ratio of nurses to patients based on the number and competence of nurses, a reduction in time pressure and a flexible service system at work can reduce nurse burnout (Dall'Ora et al., 2020).

The provision of rewards is an effort to increase job satisfaction, commitment and is expected to improve nurse caring behavior (Rusca Putra et al., 2021; Seitovirta et al., 2015). Excessive job demands, absence of rewards and lack of job promotion contribute to exhaustion and depersonalization (Basińska and Wilczek-Rużyczka, 2013). In this study it has been shown that there is a relation between appreciation and emotional exhaustion and depersonalization. This result is in accordance with several studies which state that appreciation has an influence on emotional fatigue (Laschinger et al., 2015; Liu and Lo, 2018; Nguyen et al., 2018). This result concurs with other studies which state that awards have an influence on depersonalization events (Laschinger et al., 2015). Provision of rewards that is equivalent with work achievement is an effort that can be done to lessen nurse burnout (Dall'Ora et al., 2020).

Professional status contains an important element of autonomy. Nurses have the power to control the day-to-day activities of patient care (Varjus et al., 2011). Professional nurse autonomy is the freedom that nurses feel based on self-judg- ment to make decisions using self-judgment that goes beyond standard nursing practice and is in the best interest of the patient (Both-Nwabuwe et al., 2020). Nurses with higher autonomy to make decisions have a low level of exhaustion (Dettmers and Bredehöft, 2020; Spagnoli and Molinaro, 2021). In this study it was found that there was a relation between nurse control and emotional fatigue and depersonalization. The results of this study fit with several studies which state that there is a correlation between control and emotional fatigue and nurse depersonalization (Cara et al., 2011; Laschinger et al., 2015; Liu and Lo, 2018). Burnout can be minimized through increasing nurse's practice control, variety of tasks, and decision making autonomy (Dall'Ora et al., 2020).

Based on the results of this study, hospital management needs to invest more effort to prevent and reduce the incidence of burnout among nurses. This can be done by increasing manager competency through continuous training in managing good workloads, increasing nurses' control in performing tasks, and creating a reward system which recognizes the contribution of nurses with a caring approach. It is necessary to accommodate nurses when creating a working shift schedule, obtain patient distribution according to the competence of the nurse, and receive a stress management workshop.

The limitation of this study was that the nurse sample was recruited exclusively from government general hospitals. However, the results of the study can be applied to other hospitals. Government hospitals are varied - and not only general hospitals but also military hospitals can be included. Private hospitals should also be considered for prospective studies. This is one of the studies concerning nurse managers' caring behaviors.

\section{Conclusions}

Our findings suggest that the role of nurse managers with a caring behavior approach is very important in reducing burnout among nurses. Because nurses are placed in such demanding and stressful roles, caring behaviors of nurse managers are able to positively influence the worklife of these professionals. Our results further suggest that caring behavior training to develop nurse manager skills may be a useful strategy for cultivating healthy work environments that promote occupational self-efficacy and may promote a reduction in emotional exhaustion and depersonalization. The application of caring behavior can be taught in the nursing education process. In the clinical practice, the head of ward is a role model of caring behavior towards students so that the students can apply it in providing health services. Further research on the application of nurse manager caring behavior, reward systems, workload management and autonomy of nurses in nursing practice can be carried out to determine the direct impact on burnout symptoms.

\section{Acknowledgements}

This study was funded by Directorate Research and Community Services Universitas Indonesia Hibah Tadok 2018 No.1260/ UN2.R3.1/HKP.05.00/2018.

\section{Conflict of interests}

The authors have no conflict of interests to declare. 


\section{Vliv citlivého přistupu zdravotních sester ve vedoucích pozicích na syndrom vyhoření u zdravotních sester}

\section{Souhrn}

Ošetřovatelství je povolání, které s sebou nese vysoké riziko syndromu vyhoření; ke snížení výskytu syndromu vyhoření je zapotřebí účinné organizační řízení. Tato studie si klade za cíl prozkoumat zmírňující účinky citlivého přístupu zdravotních sester ve vedoucích pozicích a dobrého pracovního prostředí na syndrom vyhoření u zdravotních sester. Tato studie využívá metodu předběžného výzkumu pro ujasnění problému v kombinaci s prưřezovým (prevalenčním) př́istupem a pracuje se vzorkem 485 zdravotních sester pracujících na chirurgických odděleních ve třech všeobecných nemocnicích v indonéské provincii Východní Jáva. Sběr dat byl proveden pomocí tři samostatných dotazníků: Maslach Burnout Inventory-Human Service Survey (MBI-HSS) k identifikaci syndromu vyhoření mezi sestrami, Caring Assessment Tool: Administration (CAT: Admn) k identifikaci citlivého přístupu u zdravotních sester ve vedoucích pozicích a My Relationship with Work test (MRW) k identifikaci kvality pracovního prostředí. Data byla analyzována pomocí metody Partial Least Square. Citlivý prŕístup zdravotních sester ve vedoucích pozicích má přímý vliv na osobní výkony zdravotních sester. Citlivý přístup zdravotních sester ve vedoucích pozicích ovlivňuje řízení, pracovní zátěž, komunitu, spravedlnost, odměňování a hodnoty, také úroveň emočního vyčerpání a odosobnění u zdravotních sester prostřednictvím odměn, řízení a pracovní zátěže.

Klíčová slova: péče; pracovní prostředí; pracovní život; syndrom vyhoření; vedoucí pracovníci; zdravotní sestry

\section{References}

1. Adriaenssens J, De Gucht VD, Maes S (2015). Determinants and prevalence of burnout in emergency nurses: A systematic review of 25 years of research. Int J Nurs Stud 52(2): 649-661. DOI: 10.1016/j.ijnurstu.2014.11.004.

2. Aiken LH, Sermeus W, Van den Heede K, Sloane DM, Busse R, McKee M, et al. (2012). Patient safety, satisfaction, and quality of hospital care: Cross sectional surveys of nurses and patients in 12 countries in Europe and the United States. BMJ 344: e1717. DOI: 10.1136/bmj.e1717.

3. Alharbi J, Wilson R, Woods C, Usher K (2016). The factors influencing burnout and job satisfaction among critical care nurses: A study of Saudi critical care nurses. J Nurs Manag 24(6): 708-717. DOI: 10.1111/jonm.12386.

4. Aronsson G, Theorell T, Grape T, Hammaström A, Hogstedt C, Marteinsdottir I, et al. (2017). A systematic review including meta-analysis of work environment and burnout symptoms. BMC Public Health 17(1): 264. DOI: 10.1186/s12889-0174153-7.

5. Basińska BA, Wilczek-Rużyczka E (2013). The role of rewards and demands in burnout among surgical nurses. Int J Occup Med Environ Health 26(4): 593-604. DOI: 10.2478/s13382013-0129-8.

6. Both-Nwabuwe JMC, Lips-Wiersma M, Dijkstra MTM, Beersma B (2020). Understanding the autonomy-meaningful work relationship in nursing: A theoretical framework. Nurs Outlook 68(1): 104-113. DOI: 10.1016/j.outlook.2019.05.008.

7. Cara CM, Nyberg JJ, Brousseau S (2011). Fostering the coexistence of caring philosophy and economics in today's health care system. Nurs Adm Q 35(1): 6-14. DOI: 10.1097/ NAQ.0b013e3182048c10.

8. Chemali Z, Ezzeddine FL, Gelaye B, Dossett ML, Salameh J, Bizri M, et al. (2019). Burnout among healthcare providers in the complex environment of the Middle East: A systematic review. BMC Public Health 19: 1337. DOI: 10.1186/s12889019-7713-1.

9. Cheng F, Meng A-F, Jin T (2015). Correlation between burnout and professional value in Chinese oncology nurses: A questionnaire survey. Int J Nurs Sci 2(2): 153-157. DOI: 10.1016/j.ijnss.2015.04.004.

10. Coetzee SK, Klopper HC, Ellis SM, Aiken LH (2013). A tale of two systems - nurses practice environment, well being, perceived quality of care and patient safety in private and public hospitals in South Africa: a questionnaire survey. Int J Nurs Stud 50(2): 162-173. DOI: 10.1016/j.ijnurstu.2012.11.002.

11. Dall'Ora C, Ball J, Reinius M, Griffiths (2020). Burnout in nursing: A theoretical review. Hum Resour Health 18(1): 41. DOI: 10.1186/s12960-020-00469-9.
12. de Carvalho DP, Rocha LP, de Pinho EC, TomaschewskiBarlem JG, Barlem ELD, Goulart LS (2019). Workloads and burnout of nursing workers. Rev Bras Enferm 72(6): 14351441. DOI: 10.1590/0034-7167-2017-0659.

13. Dettmers J, Bredehöft F (2020). The ambivalence of job autonomy and the role of job design demands. Scand J Work Org Psych 5(1): 8. DOI: 10.16993/sjwop.81.

14. Dubale BW, Friedman LF, Chemali Z, Denninger JW, Mehta DH, Alem A, et al. (2019). Systematic review of burnout among healthcare providers in sub-Saharan Africa. BMC Public Health 19: 1247. DOI: 10.1186/s12889-019-7566-7.

15. Duffy JR (2018). Quality caring in nursing and health professions: Implication for clinicians, educators, and leaders implication for clinicians, educators, and leaders third edition. New York: Springer Publishing Company, pp. 238-239.

16. Ebrahimzade N, Mooghali A, Lankarani KB, Sadati AK (2015). Relationship between nursing managers' leadership styles and nurses' job burnout: A study at Shahid Dr. Faghihi Hospital, Shiraz, Iran. Shiraz E Med J 16(8). DOI: 10.17795/semj27070.

17. Hailay A, Aberhe W, Mebrahtom G, Zereabruk K, Gebreayezgi G, Haile T (2020). Burnout among nurses working in Ethiopia. Behav Neurol 2020: 8814557. DOI: 10.1155/2020/8814557.

18. Hamed RA, Abd Elaziz SY, Ahmed AS (2020). Prevalence and predictors of burnout syndrome, post-traumatic stress disorder, depression, and anxiety in nursing staff in various departments. Middle East Current Psychiatry 27(1). DOI: 10.1186/s43045020-00044-x.

19. Harkin M, Melby V (2014). Comparing burnout in emergency nurses and medical nurses. Crit Nurs Stud 2(3): 152-163. DOI: $10.5430 / \mathrm{cns} . v 2 \mathrm{n} 3 \mathrm{p} 152$.

20. Havaei F, Astivia OLO, MacPhee M (2020). The impact of workplace violence on medical-surgical nurses' health outcome: A moderated mediation model of work environment conditions and burnout using secondary data. Int J Nurs Stud 109: 103666. DOI: 10.1016/j.ijnurstu.2020.103666.

21. Holland PJ, Allen BC, Cooper BK (2013). Reducing burnout in Australian nurses: The role of employee direct voice and managerial responsiveness. Int J Hum Res Manag 24(16): 3146-3162. DOI: 10.1080/09585192.2013.775032.

22. Kim, LY, Rose DE, Ganz DA, Giannitrapani KF, Yano EM, Rubenstein LV, Stockdale SE (2020). Elements of the healthy work environment associated with lower primary care nurse burnout. Nurs Outlook 68(1): 14-25. DOI: 10.1016/j. outlook.2019.06.018.

23. Laschinger HKS, Borgogni L, Consiglio C, Read E (2015). The effects of authentic leadership, six areas of worklife, and occupational coping self-efficacy on new graduate nurses' burnout and mental health: A cross-sectional study. Int J Nurs Stud 52(6):1080-1089. DOI: 10.1016/j. ijnurstu.2015.03.002. 
24. Lee EK, Ji EJ (2018). The moderating role of leader-member exchange in the relationships between emotional labor and burnout in clinical nurses. Asian Nurs Res 12(1): 56-61. DOI: 10.1016/j.anr.2018.02.002.

25. Leiter MP, Maslach C (2005). Banishing Burnout: Six Strategies for Improving Your Relationship with Work. 1st ed. SSRN Electronic Journal. Edited by Jossey-Bass. San Francisco. DOI: $10.2139 /$ ssrn.1966524.

26. Liu H-L, Lo V-H (2018). An integrated model of workload, autonomy, burnout, job satisfaction, and turnover intention among Taiwanese reporters. Asian J Com 28(2): 153-169. DOI: 10.1080/01292986.2017.1382544.

27. Longo J (2011). Acts of caring: Nurses caring for nurses. Holist Nurs Pract 25(1): 8-16. DOI: 10.1097/HNP.0b013e3181fe2627.

28. Madathil R, Heck NC, Schuldberg D (2014). Burnout in psychiatric nursing: Examining the interplay of autonomy, leadership style, and depressive symptoms. Arch Psychiatr Nurs 28(3): 160-166. DOI: 10.1016/j.apnu.2014.01.002.

29. Mahmoudi S, Barkhordari-Sharifabad M, Pishgooie A-H, Atashzadeh-Shoorideh F, Lotfi Z (2020). Burnout among Iranian nurses: A national survey. BMC Nurs 19: 69. DOI: 10.1186/ s12912-020-00461-7.

30. Maslach C, Leiter MP (2008). Early predictors of job burnout and engagement. J Appl Psychol 93(3): 498-512. DOI: 10.1037/0021-9010.93.3.498.

31. McCormack N, Cotter C (2013). Managing burnout in the workplace: A guide for information professionals. New Delhi: Chandos Publishing, pp. 28-48.

32. Mo S, Shi J (2017). Linking ethical leadership to employee burnout, workplace deviance and performance: Testing the mediating roles of trust in leader and surface acting. J Bus Ethics 144(2): 293-303. DOI: 10.1007/s10551-015-2821-z.

33. Molero MDM, Pérez-Fuentes MDC, Gázquez JJ (2018). Analysis of the mediating role of self-efficacy and self-esteem on the effect of workload on burnout's influence on nurses' plans to work longer. Front Psychol 9: 2605. DOI: 10.3389/ fpsyg.2018.02605.

34. Mudallal RH, Othman WM, Al Hassan NF (2017). Nurses' burnout: The influence of leader empowering behaviors, work condition, and demographic traits. Inquiry 54: 46958017724944. DOI: 10.1177/0046958017724944.

35. Nguyen HTT, Kitaoka K, Sukigara M, Thai AL (2018). Burnout study of clinical nurses in Vietnam: Development of job burnout model based on Leiter and maslach's theory. Asian Nurs Res 12(1): 42-49. DOI: 10.1016/j.anr.2018.01.003.

36. Nishimura K, Nakamura F, Takegami M, Fukuhara S, Nakagawara J, Ogasawara K, et al. (2014). Cross-sectional survey of workload and burnout among japanese physicians working in stroke care the nationwide survey of acute stroke care capacity for proper designation of comprehensive stroke center in Japan (J-ASPECT) study. Circ Cardiovasc Qual Outcomes 7(3): 414-422. DOI: 10.1161/ CIRCOUTCOMES.113.000159.

37. Nobre DFR, Rabiais ICM, Ribeiro PCPSV, Saebra PRC (2019). Burnout assessment in nurses from a general emergency service. Rev Bras Enferm 72(6): 1457-1463. DOI: 10.1590/0034-7167-2017-0870.

38. Oshodi TO, Bruneau B, Crockett R, Kinchington F, Nayar S, West $\mathrm{E}$ (2019). The nursing work environment and quality of care : Content analysis of comments made by registered nurses responding to the essentials of magnetism II scale. Nurs Open 6(3): 878-888. DOI: 10.1002/nop2.268.

39. Phillips C (2020). Relationships between workload perception, burnout, and intent to leave among medical-surgical nurses.
Int J Evid Based Healthc 18(2): 265-273. DOI: 10.1097/ XEB.0000000000000220.

40. Ramirez-Baena L, Ortega-Campos E, Gomez-Urquiza JL, Cañadas-De la Fuente GR, De la Fuente-Solana EI, Cañadas-De la Fuente GA (2019). A multicentre study of burnout prevalence and related psychological variables in medical area hospital nurses. J Clin Med 8(1): 92. DOI: 10.3390/jcm8010092.

41. Roche MA, Laschinger HKS, Duffield C (2015). Testing the nursing worklife model in Canada and Australia: A multigroup comparasion study. Int J Nurs Stud 52(2): 525-534. DOI: 10.1016/j.ijnurstu.2014.10.016.

42. Rusca Putra, K, Andayani T, Ningrum EH (2021). Job satisfaction and caring behavior among nurses in a military hospital: A cross-sectional study. J Pub Health Res 10(2): 313-316. DOI: 10.4081/jphr.2021.2212.

43. Seitovirta J, Partanen P, Vehvilainen-Julkunen K, Kvist T (2015). Registered nurses' experiences of rewarding in a Finnish University Hospital - an interview study. J Nurs Manag 23(7): 868-878. DOI: 10.1111/jonm.12228.

44. Shah MK, Gandrakota N, Cimiotti JP, Ghose N, Moore M, Ali MK (2021). Prevalence of and factors associated with nurse burnout in the US. JAMA Netw Open 4(2): e2036469. DOI: 10.1001/jamanetworkopen.2020.36469.

45. Shen A, Wang Y, Qiang W (2018). A multicenter investigation of caring behaviors and burnout among oncology nurses in China. Cancer Nurs 43(5): E246-E253. DOI: 10.1097/ ncc.0000000000000680.

46. Spagnoli P, Molinaro D (2021). Negative (Workaholic) emotions and emotional exhaustion: Might job autonomy have played a strategic role in workers with responsibility during the COVID-19 crisis lockdown? Behav Sci (Basel) 10(12): 192. DOI: $10.3390 /$ bs10120192.

47. Tafvelin S, Nielsen K, Schwarz UT, Stenling A (2019). Leading well is matter of resources: Leader vigour and peer support augments the relationship between transformational leadership and burnout. Work \& Stres 33(2): 156-172. DOI: 10.1080/02678373.2018.1513961.

48. Tang FWK, Ling GCC, Lai ASF, Chair SY, So WKW (2019). Four Es of caring in contemporary nursing: Exploring novice to experienced nurses. Nurs Health Sci 21(1): 85-92. DOI: $10.1111 /$ nhs.12561.

49. Varjus S-L, Leino-Kilpi H, Suominen T (2011). Professional autonomy of nurses in hospital settings - a review of the literature. Scand J Caring Sci 25(1): 201-207. DOI: 10.1111/j.1471-6712.2010.00819.x.

50. Waddill-Goad SM (2019). Stress, fatigue, and burnout in nursing. J Rad Nurs 38(1): 44-46. DOI: 10.1016/j. jradnu.2018.10.005.

51. Wolverton CL, Lasiter S, Duffy JR, Weaver MT, McDaniel AM (2018). Psychometric testing of the caring assessment tool: administration. SAGE Open Med 6: 2050312118760739. DOI: $10.1177 / 2050312118760739$.

52. Woo T, Ho R, Tang A, Tam W (2020). Global prevalence of burnout symptoms among nurses: A systematic review and meta-analysis. J Psychi Res 123(August 2019): 9-20. DOI: 10.1016/j.jpsychires.2019.12.015.

53. Yuan C-M, Xu C-Y (2020). Concept analysis of nurse burnout. Front Nurs 7(3): 227-233. DOI: 10.2478/fon-2020-0034.

54. Zhang L-F, You L-M, Liu K, Zheng J, Fang J-B, Lu M-M, et al. (2014). The association of Chinese hospital work environment with nurse burnout, job satisfaction, and intention to leave. Nurs Outlook 62(2): 128-137. DOI: 10.1016/j. outlook.2013.10.010. 